\title{
KERUGIAN KONTRAKTOR AKIBAT WASTE MATERIAL PROYEK KONSTRUKSI GEDUNG BERTINGKAT
}

\author{
Hendrik Sulistio $^{1)}$ dan Mega Waty $^{2)}$ \\ 1) Program Doktor Teknik Sipil, Universitas Tarumanagara, Jakarta, DKI Jakarta \\ 2) Program Sarjana Teknik Sipil, Universitas Tarumanagara, Jakarta, DKI Jakarta \\ hendriks@ft.untar.ac.id
}

\begin{abstract}
Waste in the construction sector can be interpreted as loss or loss of various resources, namely material, time (related to labor and equipment), and capital, which is caused by activities that require direct or indirect costs but do not add value to the final product for service users This study was conducted on 64 respondents of building construction projects to determine the magnitude of losses due to ready mix concrete and its causes. Research using a questionnaire distributed through the online system. Of the 64 respondents produced $9.06 \%$ which is the loss of ready mix concrete. The loss of Ready Mix concrete is $9.06 \%$ of the profit of Ready Mix Concrete. The validity test and reliability test produced 18 causative factors that caused the loss of ready mix concrete material waste. The biggest factors causing the loss of ready mix concrete are: lost due to being stolen, design changes, detailed drawing details and material orders that are not according to specifications and scattered when transported/moved.
\end{abstract}

Keywords: waste material, ready mix concrete, the causative factor

\begin{abstract}
ABSTRAK
Waste dalam bidang konstruksi dapat diartikan sebagai kehilangan atau kerugian berbagai sumber daya yaitu material, waktu (yang berkaitan dengan tenaga kerja dan peralatan) dan modal, yang di akibatkan oleh kegiatan-kegiatan yang membutuhkan biaya secara langsung maupun tidak langsung tetapi tidak menambah nilai kepada produk akhir bagi pihak pengguna jasa Penelitian ini dilakukan pada 64 responden proyek konstruksi gedung untuk mengetahui besarnya kerugian akibat beton ready mix dan penyebabnya. Penelitian dengan menggunakan kuesioner yang disebarkan melalui system online. Dari 64 responden menghasilkan $9.06 \%$ yang merupakan kerugian beton ready mix. Kerugian beton Ready Mix adalah $9.06 \%$ dari profit Beton Ready Mix. Dari uji validitas dan uji reliabilitas menghasilkan 18 faktor penyebab yang menyebabkan kerugian waste material beton ready mix. Faktor Penyebab kerugian beton ready mix yang terbesar adalah: hilang karena dicuri, adanya perubahan desain, pendetailan gambar yang rumit dan pesanan material yang tidak sesuai dengan spesifikasi dan tercecer pada saat diangkut/dipindahkan.
\end{abstract}

Kata kunci: waste material, beton ready mix, faktor penyebab 


\section{PENDAHULUAN}

Material sebagai salah satu komponen yang mempunyai kontribusi sebesar $40-60 \%$ dari biaya proyek (Ritz, 1994 dalam Intan, Alifen, \& Arijanto, 2005) yang menyatakan bahwa material turut memegang peranan penting dalam menunjang keberhasilan suatu proyek. Waste dalam bidang konstruksi dapat diartikan sebagai kehilangan atau kerugian berbagai sumber daya yaitu material, waktu (yang berkaitan dengan tenaga kerja dan peralatan) dan modal, yang di akibatkan oleh kegiatan-kegiatan yang membutuhkan biaya secara langsung maupun tidak langsung tetapi tidak menambah nilai kepada produk akhir bagi pihak pengguna jasa konstruksi (Formoso, Soibelman, De Cesare, \& Isatto, 2002). Penelitian dari Intan et al. (2005), menyatakan penelitian terhadap kuantitas material waste yang paling banyak pada proyek gedung yakni batu bata dan pasir sebesar $12.51 \%$ dan pasir $11.39 \%$. Intan et al. (2005) melakukan penelitian pada bangunan ruko di Surabaya.

Penelitian saat ini dilakukan untuk mengetahui besarnya kerugian waste material beton ready mix yang dialami kontraktor dan penyebabnya. Penelitian difokuskan di Jakarta sebagai ibukota negara dan kota metropolitan dimana sedang giatnya melakukan pembangunan pada proyek gedung bertingkat yang mana fokus bangunan bertingkat pada Gedung berlantai di atas 8 tingkat.

\section{KAJIAN PUSTAKA}

Material konstruksi merupakan komponen yang penting dalam menentukan besarnya biaya suatu proyek, lebih dari separuh biaya proyek diserap oleh material yang digunakan (Nugraha, 1985). Pada tahap pelaksanaan konstruksi penggunaan material di lapangan sering terjadi material waste yang cukup besar, sehingga upaya untuk meminimalisi material waste penting untuk diterapkan. Material yang digunakan dalam pelaksanaan konstruksi dapat digolongkan dalam dua bagian besar antara lain: consumable material, merupakan material yang pada akhirnya akan menjadi bagian dari struktur fisik bangunan, misalnya semen, pasir, kerikil, batu pecah, baja tulangan, keramik, cat dan lain- lain (Gavilan \& Bernold, 1994).

Material waste yang terjadi dalam pelaksanaan konstruksi cukup tinggi dan sangat sulit diukur secara sistematik (Formoso et al., 2002). Pada saat ini, jenis bahan yang dapat digunakan untuk konstruksi sipil sangat beragam dan semakin berkembang dari segi kualitas maupun estetika keindahannya. Peningkatan kualitas umumnya untuk 
mendapatkan bahan yang semakin kuat dengan daya tahan tinggi tetapi harganya tetap atau sering kali lebih murah, sedangkan dari segi keindahannya berupa tersedianya berbagai macam bentuk dan varian bahan konstruksi di pasaran.

Jenis lain dari bahan di luar dari material waste juga perlu diketahui. Dalam penelitian Intan et al. (2005) menyatakan Skoyles (1976), membuat perbedaan antara material waste langsung dan material waste tidak langsung. Material waste langsung terdiri dari hilangnya bahan karena rusak dan tidak dapat digunakan lagi. Sebaliknya material waste tidak langsung terjadi ketika bahan secara fisik tidak hilang melainkan pemborosan biaya untuk bahan material semakin banyak, misalnya karena penggunaan bahan material beton lebih tebal dari desain pengerjaan yang telah ditentukan.

\subsection{Faktor-faktor penyebab terjadinya Material waste}

Banyak faktor yang dapat menyebabkan terjadinya material waste di lapangan. Material waste yang terjadi dapat disebabkan oleh satu atau kombinasi dari beberapa penyebab. Gavilan \& Bernold (1994), membedakan sumber-sumber yang dapat menyebabkan terjadinya material waste konstruksi atas enam kategori yaitu:

1. Desain
2. Pengadaan material

3. Penanganan material

4. Pelaksanaan

5. Residual

6. Dan lain- lain

\subsection{Proyek gedung}

Gedung sebagai salah satu prasarana yang merupakan unsur penting dalam pengembangan kehidupan berbangsa dan bernegara, dalam pembinaan persatuan dan kesatuan bangsa, wilayah Negara, dan fungsi masyarakat serta dalam memajukan kesejahteraan umum sebagaimana dimaksudkan dalam Pembukaan UndangUndang Dasar Negara Republik Indonesia Tahun 1945.

\section{METODE PENELITIAN}

Metode pengumpulan data hanya satu cara macam yaitu penyebaran kuesioner kepada responden dalam jumlah yang cukup banyak yaitu 100 responden tetapi yang mengembalikan adalah 64 responden yang tersebar pada proyek gedung bertingkat di Jakarta, diatas 8 lantai yang bertujuan untuk mendapatkan gambaran atau uraian tentang kuantitas sisa material yang terjadi di lapangan pada Gedung bertingkat. Penyebaran kuesioner dilakukan via online lewat internet dilapangan dan yang terbanyak adalah wawancara via telepon. Hal ini dilakukan agar tidak 
mengganggu proses pelaksanaan konstruksi di lapangan, selain itu agar peneliti dapat berkomunikasi langsung dengan responden sehingga isi pertanyaan dalam kuesioner dapat dimengerti dan dipahami oleh responden.
Tabel 1 menunjukkan faktor-faktor penyebab waste material beton ready mix dari berbagai referensi yang dapat dilihat di bawah ini.

Tabel 1. Faktor Faktor Penyebab Waste Material Beton Ready Mix

\begin{tabular}{|c|c|c|}
\hline Sumber & Penyebab & Referensi \\
\hline \multirow[t]{4}{*}{ Desain } & Adanya perubahan desain & (Bossink \& Brouwers, 1996) \\
\hline & Informasi gambar kurang/tidak jelas & (Bossink \& Brouwers, 1996) \\
\hline & Pendetailan gambar yang rumit & (Bossink \& Brouwers, 1996) \\
\hline & $\begin{array}{l}\text { Kurang berkoordinasi terhadap dimensi produk } \\
\text { yang digunakan }\end{array}$ & (Bossink \& Brouwers, 1996) \\
\hline \multirow[t]{4}{*}{ Pengadaan } & Pesanan material tidak sesuai spesifikasi & (Bossink \& Brouwers, 1996) \\
\hline & Pemesanan melebihi kebutuhan & (Bossink \& Brouwers, 1996) \\
\hline & Pesanan tidak dapat dilakukan dalam jumlah kecil & (Bossink \& Brouwers, 1996) \\
\hline & Supplier kirim material tidak sesuai spesifikasi & (Bossink \& Brouwers, 1996) \\
\hline \multirow[t]{4}{*}{$\begin{array}{l}\text { Penanganan } \\
\text { material }\end{array}$} & $\begin{array}{l}\text { Penanganan yang tidak hati-hati/kecelakaan pada } \\
\text { saat menuangkan beton }\end{array}$ & (Bossink \& Brouwers, 1996) \\
\hline & Volume beton dari levaransir kurang & (Bossink \& Brouwers, 1996) \\
\hline & Beton mengeras karena penanganan lambat & (Intan et al., 2005) \\
\hline & Tercecer pada saat diangkut/dipindahkan & (Intan et al., 2005) \\
\hline \multirow[t]{4}{*}{ Pelaksanaan } & Cuaca yang buruk/hujan & (Bossink \& Brouwers, 1996) \\
\hline & Pengukuran dimensi tidak akurat & (Bossink \& Brouwers, 1996) \\
\hline & $\begin{array}{l}\text { Terjadi deviasi dimensi struktur pada saat } \\
\text { pengecoran }\end{array}$ & (Intan et al., 2005) \\
\hline & $\begin{array}{l}\text { Letak tiang pancang bergeser menyebabkan } \\
\text { volume poer/sloof bertambah }\end{array}$ & (Intan et al., 2005) \\
\hline Residual & Sisa material pada akhir pekerjaan & (Bossink \& Brouwers, 1996) \\
\hline Lain-lain & Hilang karena dicuri & (Bossink \& Brouwers, 1996) \\
\hline
\end{tabular}

\subsection{Variabel penelitian}

Pada tahap pengumpulan data, Proses pengumpulan data yang dilakukan adalah dengan menyebar kuesioner di proyek bangunan gedung bertingkat yang berada di Jakarta. Dalam kuesioner ini terdapat variabel bebas $(\mathrm{X})$ merupakan faktor yang mempengaruhi beton ready mix. Proses pengumpulan data dilakukan melalui penyebaran kuisioner terhadap pihak manajemen dari proyek yang bersangkutan. Untuk pengukuran nilai kuesioner digunakan teknik pengukuran likert keterangan untuk skala pengukuran faktor yang mempengaruhi kerugian beton ready mix pada proyek konstruksi dari 1 hingga 6 
yakni dari sangat tidak berpengaruh hingga sangat berpengaruh sekali.

\subsection{Pengolahan data}

Pada proses pengolahan data, datadata yang telah dikumpulkan kemudian diolah dan dicatat dalam bentuk tabel dalam excel. Untuk urutan pengolahan data, pertama dilakukan analisa deskriptif dan setelah itu dilakukan uji validitas dan uji reliabilitas. Setelah itu faktor-faktor tersebut diberi peringkat dengan metode Relative Importance Index.

\subsubsection{Uji Validitas}

Uji validitas merupakan pengujian tingkat kendala dan kesahan alat ukur yang digunakan. Instrumen dikatakan valid berarti menunjukkan alat ukur yang dipergunakan untuk mendapat data itu valid atau dapat digunakan untuk mengukur apa yang seharusnya diukur. Dengan demikian, instrumen yang valid merupakan instrumen yang benar-benar tepat untuk mengukur apa yang hendak diukur. Uji validitas yang digunakan adalah dengan uji pearson product momen (Waty \& Sulistio, 2020).

Pengukuran validitas dengan membandingkan nilai $r$ perhitungan (Product Moment) dengan nilai $\mathrm{r}$ pada tabel. Jika nilai $r$ hitung $\geq r$ tabel, maka data tersebut sudah valid (Sugiyono, 2010). Rumus yang digunakan untuk mencari koefisien Product Moment yaitu (Pearson, 1896):

$$
\mathrm{r}_{\mathrm{xy}}=\frac{\mathrm{n} \sum \mathrm{xy}-\left(\sum \mathrm{x}\right)\left(\sum \mathrm{y}\right)}{\sqrt{\left(\mathrm{n} \sum \mathrm{x}^{2}-\left(\sum \mathrm{x}\right)^{2}\right)\left(\mathrm{n} \sum \mathrm{y}^{2}-\left(\sum \mathrm{y}\right)^{2}\right)}} \ldots \ldots
$$

keterangan:

$\mathrm{x}$ : skor yang diperoleh subjek dari seluruh item

y : skor total yang diperoleh dari seluruh item

$\Sigma \mathrm{x}:$ jumlah skor dalam distribusi $\mathrm{x}$

$\Sigma y$ : jumlah skor dalam distribusi y $\Sigma \mathrm{x}^{2}$ : jumlah kuadrat dalam skor distribusi $\mathrm{x}$

$\Sigma \mathrm{y}^{2}$ : jumlah kuadrat dalam skor distribusi y

$\mathrm{n}$ : banyaknya responden

\subsubsection{Uji Reliabilitas}

Uji reliabilitas adalah pengujian suatu kestabilan dan konsistensi responden dalam menjawab hal yang berkaitan dengan konstruk-konstruk pertanyaan yang merupakan dimensi suatu variabel dan disusun dalam suatu bentuk kuesioner. Maka setelah dilakukan uji validitas, dilanjutkan dengan menggunakan uji reliabilitas data. Alat ukur yang reliabel pasti terdiri dari item-item alat ukur yang valid, sehingga, setiap reliabel pasti valid, namun setiap yang valid belum tentu reliable (Waty \& Sulistio, 2020).

Rumus yang digunakan uji reliabilitas ini adalah Alpha Cronbach. Pengujian 
dilakukan dengan bantuan program terapan, dan butir pertanyaan yang sudah valid dalam uji validitas ditentukan reliabilitasnya dengan kriteria: (1) jika ralpha positif atau lebih besar dari rtabel, maka pernyataan reliabel dan (2) jika ralpha negatif atau lebih besar dari rtabel, maka pernyataan tidak reliabel. Salah satu keandalan variabel yang menunjukkan sejauh mana indikator yang berbeda untuk faktor laten yang dimiliki (Garson, 2009), adalah yang menyatakan bahwa akan diterima memuaskan jika Cronbach's Alpha koefisien yang dilaporkan untuk setiap item lebih besar dari ambang nilai 0.7 direkomendasikan oleh Nunnally (1994) dan (Hair, Black, Babin, Anderson, \& Tatham, 1998). Menurut Gozali (2001) keandalan akan diterima memuaskan jika cronbach's alpha koefisien yang dilaporkan lebih besar daripada nilai ambang 0.6

Rumus untuk mencari nilai cronbach's alpha adalah sebagai berikut (Cronbach, 1951):

$$
\mathrm{r}_{11}=\left(\frac{\mathrm{n}}{\mathrm{n}-1}\right)\left(1-\frac{\sum \sigma_{\mathrm{t}}^{2}}{\sigma_{\mathrm{t}}^{2}}\right)
$$

keterangan:

$\mathrm{r}_{11}$ : koefisien reliabilitas (nilai cronbach's alpha)

n : banyak butiran pernyataan

$\sigma_{t}^{2}$ : jumlah varians skor total
$\Sigma \sigma_{i}^{2}:$ jumlah varians skor soal kei

\subsubsection{Relative Importance Index}

Kometa, Olomolaiye, \& Harris (1994) dan Sambasivan \& Soon (2007) menggunakan metode Relative Importance Index untuk menentukan kepentingan relatif dari berbagai penyebab penundaan. Metode ini pula yang dipakai dalam penelitian ini. Setelah didapat data dari kuesioner berupa skala likert dengan skala 1-6, dimana Skala 1 menunjukan faktor sangat tidak berpengaruh terhadap beton ready mix dan skala 6 menunjukan faktor sangat berpengaruh terhadap beton ready mix (Linkert, 1932). Setelah beberapa variabel/faktor dieliminasi dengan uji validitas dan reliabilitas, langkah selanjutnya dilakukan Relative Importance Index untuk mengetahui peringkat faktor yang mempengaruhi beton ready mix. Cicchetti (1994) menjelaskan bila hasil suatu survey berada di antara angka 0.75 hingga 1 , dikatakan hasilnya sangat bagus demikian juga bila RII menghasilkan angka antara 0.75 hingga 1 dikatakan sangat bagus hasilnya.

Relative Importance Index dapat dihitung menggunakan rumus dibawah ini:

$$
\begin{aligned}
& \text { RII }(\%)= \\
& \frac{6 n_{6}+5 n_{5}+4 n_{4}+3 n_{3}+2 n_{2}+1 n_{1}}{W^{*}\left(n_{6}+n_{5}+n_{4}+n_{3}+n_{2}+n_{1}\right)} \times 100 \%
\end{aligned}
$$


keterangan:

$\mathrm{n}_{6}:$ Jumlah responden yang memilih skala 6

$\mathrm{n}_{5}$ : Jumlah responden yang memilih skala 5

$\mathrm{n}_{4}:$ Jumlah responden yang memilih skala 4

$\mathrm{n}_{3}$ : Jumlah responden yang memilih skala 3

$\mathrm{n}_{2}$ : Jumlah responden yang memilih skala 2

$\mathrm{n}_{1}:$ Jumlah responden yang memilih skala 1

W : Skala terbesar dalam skala Likert

\section{HASIL DAN PEMBAHASAN}

Obyek penelitian utama ini adalah supervisor, site engineer, project manager, project director, quantity surveyor dan pihak-pihak lainnya yang menjadi staff pada proyek gedung bertingkat. Total responden yang berpartisipasi dalam penelitian ini berjumlah 64 orang. Di bawah ini akan dilampirkan data responden berupa tingkat pendidikan, pengalaman bekerja di bidang konstruksi, juga posisi atau jabatan dalam proyek konstruksi.

Gambar 1 menjelaskan bahwa dari 64 responden, sebanyak 45 responden berpengalaman di bawah 10 tahun setara dengan $70.31 \%$ dari total responden.
Responden berpengalaman diatas 10 tahun sebanyak 19 orang atau setara dengan 29.69 $\%$ dari total responden.

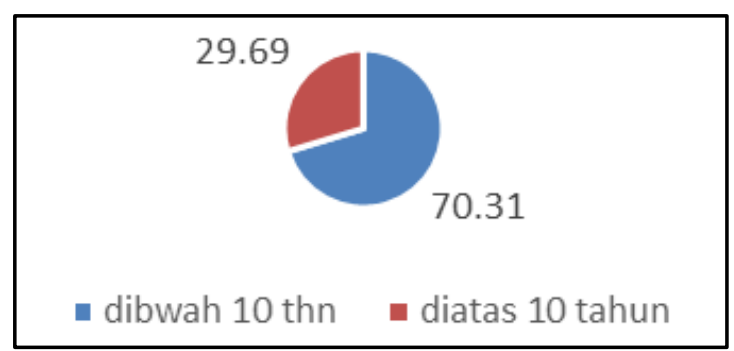

Gambar 1. Pengalaman Responden

Gambar 2 menjelaskan bahwa dari 64 responden yang memiliki jabatan sebagai staf sebanyak $21.87 \%$ dan jabatan sebagai manajer sebanyak 78.12\%. Berarti responden kebanyakan jabatan sebagai manajer dan diatasnya.

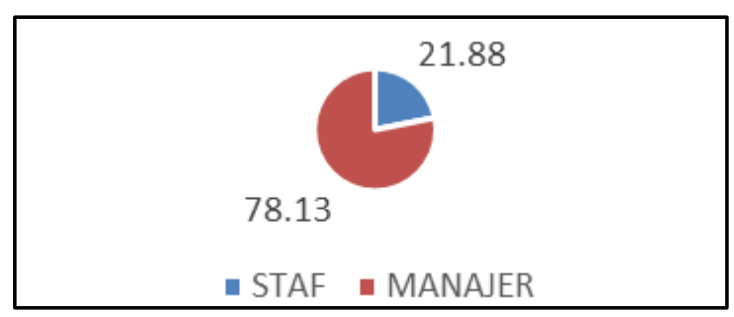

Gambar 2. Jabatan Responden

\subsection{Kuantitas sisa material beton ready mix \\ Data 64 responden yang mengisi data} didapat rata rata sebesar $9.06 \%$ merupakan kerugian beton ready mix. Diasumsikan untuk suatu proyek dengan nilai kontrak anggaran biaya untuk beton ready mix yakni $1000 \mathrm{~m}^{3}$ x Rp.1,000,000.00 = Rp. 1,000,000,000.00. Keuntungan $10 \%$ sebesar Rp. 100,000,000.00. 
Kerugian $9.06 \%$ x Rp. 100,000,000 = Rp. 9,060,000.00 dari keuntungan Rp.100,000,000.00.

\subsection{Uji Validitas}

Dari hasil uji diatas menunjukkan seluruh faktor yang mempengaruhi sisa material baik dari desain hingga lain lain dapat dipergunakan yang dapat dilihat pada Tabel 2 hingga Tabel 6.

\subsubsection{Uji Validitas Desain}

Uji validitas desain menghasilkan desain dari desain 1 hingga desain 4 menghasilkan nilai validitas yang tinggi yang dilihat dari nilai $\mathrm{R}$ hitung yang dinyatakan dalam skor total dimana nilai yang dihasilkan melebihi $\mathrm{R}$ tabel momen product (0.244) sehingga semua faktor yang berpengaruh di dalamnya layak dipergunakan (Tabel 2).

Tabel 2. Output Validitas Desain

\begin{tabular}{|c|c|c|c|c|c|c|}
\hline \multicolumn{7}{|c|}{ Correlations } \\
\hline & & Desain 1 & Desain 2 & Desain 3 & Desain4 & Skor Total \\
\hline \multirow[t]{3}{*}{ DESAIN 1} & $\begin{array}{c}\text { Pearson } \\
\text { Correlation }\end{array}$ & 1 & $.673^{* *}$ & $.590^{* * *}$ & $.444^{* *}$ & $.803^{* *}$ \\
\hline & Sig. (2-tailed) & & .000 & .000 & .000 & .000 \\
\hline & $\mathrm{N}$ & 64 & 64 & 64 & 64 & 64 \\
\hline \multirow[t]{3}{*}{ DESAIN 2} & $\begin{array}{l}\text { Pearson } \\
\text { Correlation }\end{array}$ & $.673^{* *}$ & 1 & $.559^{* * *}$ & $.503^{* *}$ & $.827^{* *}$ \\
\hline & Sig. (2-tailed) & ,000 & & ,000 & ,000 & ,000 \\
\hline & $\mathrm{N}$ & 64 & 64 & 64 & 64 & 64 \\
\hline \multirow[t]{3}{*}{ DESAIN 3} & $\begin{array}{l}\text { Pearson } \\
\text { Correlation }\end{array}$ & $.590^{* *}$ & $.559^{* *}$ & 1 & $.556^{* *}$ & $.837^{* *}$ \\
\hline & Sig. (2-tailed) & .000 & .000 & & .000 & .000 \\
\hline & $\mathrm{N}$ & 64 & 64 & 64 & 64 & 64 \\
\hline \multirow[t]{3}{*}{ DESAIN 4} & $\begin{array}{l}\text { Pearson } \\
\text { Correlation }\end{array}$ & $.444^{* *}$ & $.503^{* *}$ & $.556^{* *}$ & 1 & $.792^{* *}$ \\
\hline & Sig. (2-tailed) & .000 & .000 & .000 & & .000 \\
\hline & $\mathrm{N}$ & 64 & 64 & 64 & 64 & 64 \\
\hline \multirow[t]{3}{*}{ SKOR TOTAL } & $\begin{array}{c}\text { Pearson } \\
\text { Correlation }\end{array}$ & $.803^{* *}$ & $.827^{* *}$ & $.837^{* *}$ & $.792^{* *}$ & 1 \\
\hline & Sig. (2-tailed) & .000 & .000 & .000 & .000 & \\
\hline & $\mathrm{N}$ & 64 & 64 & 64 & 64 & 64 \\
\hline
\end{tabular}

**: Correlation is significant at the 0.01 level (2-tailed)

\subsubsection{Uji Validitas Pengadaan}

Uji validitas pengadaan menghasilkan nilai skor total pengadaan dari pengadaan 1 hingga pengadaan 4 menghasilkan nilai validitas yang yang melebihi tabel $\mathrm{R}$ momen product $(0.244)$ dimana skor total menunjukkan hasil diatas nilai tabel $\mathrm{R}$ momen product sehingga semua faktor yang berpengaruh di dalamnya layak dipergunakan (Tabel 3). 
Tabel 3. Output Validitas Pengadaan

\begin{tabular}{|c|c|c|c|c|c|c|}
\hline \multicolumn{7}{|c|}{ Correlations } \\
\hline & & Pengadaan 1 & Pengadaan 2 & Pengadaan 3 & Pengadaan 4 & $\begin{array}{l}\text { skor } \\
\text { total }\end{array}$ \\
\hline \multirow[t]{4}{*}{ pengadaan 1} & Pearson & 1 & $.666^{* *}$ & $.420^{* * *}$ & $.381^{* *}$ & $.791^{* *}$ \\
\hline & Correlation & & & & & \\
\hline & Sig. (2-tailed) & & .000 & .001 & .002 & .000 \\
\hline & $\mathrm{N}$ & 64 & 64 & 64 & 64 & 64 \\
\hline \multirow[t]{4}{*}{ pengadaan 2} & Pearson & $.666^{* *}$ & 1 & $.505^{* *}$ & .199 & $.743^{* *}$ \\
\hline & Correlation & & & & & \\
\hline & Sig. (2-tailed) & .000 & & , 000 & .114 & .000 \\
\hline & $\mathrm{N}$ & 64 & 64 & 64 & 64 & 64 \\
\hline \multirow[t]{4}{*}{ pengadaan 3} & Pearson & $.420^{* *}$ & $.505^{* *}$ & 1 & $.568^{* *}$ & $.809^{* *}$ \\
\hline & Correlation & & & & & \\
\hline & Sig. (2-tailed) & .001 & .000 & & .000 & .000 \\
\hline & $\mathrm{N}$ & 64 & 64 & 64 & 64 & 64 \\
\hline \multirow[t]{3}{*}{ pengadaan 4} & Pearson & $.381^{* *}$ & .199 & $.568^{* *}$ & 1 & $.732^{* *}$ \\
\hline & Sig. (2-tailed) & .002 & .114 & .000 & & .000 \\
\hline & $\mathrm{N}$ & 64 & 64 & 64 & 64 & 64 \\
\hline \multirow[t]{4}{*}{ skor total } & Pearson & $.791^{* *}$ & $.743^{* *}$ & $.809^{* *}$ & $.732^{* *}$ & 1 \\
\hline & Correlation & & & & & \\
\hline & Sig. (2-tailed) & .000 & .000 & .000 & .000 & \\
\hline & $\mathrm{N}$ & 64 & 64 & 64 & 64 & 64 \\
\hline
\end{tabular}

\subsubsection{Uji Validitas Penanganan}

Uji validitas penanganan menghasilkan nilai skor total pengadaan dari pengadaan 1 hingga pengadaan 4 menghasilkan nilai validitas yang yang melebihi tabel $\mathrm{R}$ momen product (0.244) dimana skor total menunjukkan hasil diatas nilai tabel $\mathrm{R}$ momen product sehingga semua faktor yang berpengaruh di dalamnya layak dipergunakan (Tabel 4).

\subsubsection{Uji Validitas Pelaksanaan}

Uji validitas pelaksanaan menghasilkan menghasilkan nilai skor total pengadaan dari pengadaan 1 hingga pengadaan 4 menghasilkan nilai validitas yang yang melebihi tabel $\mathrm{R}$ momen product (0.244) dimana skor total menunjukkan hasil diatas nilai tabel $\mathrm{R}$ momen product sehingga semua faktor yang berpengaruh di dalamnya layak dipergunakan (Tabel 5).

\subsubsection{Uji Validitas Residual dan lain lain}

Uji validitas menghasilkan menghasilkan nilai skor total residual dari residual hingga lain lain menghasilkan nilai validitas yang yang melebihi tabel $\mathrm{R}$ momen product $(0.244)$ dimana skor total menunjukkan hasil diatas nilai tabel $\mathrm{R}$ momen product sehingga semua faktor yang berpengaruh di dalamnya layak dipergunakan (Tabel 6). 
Tabel 4 .Output Validitas Penanganan

\begin{tabular}{ccccccc}
\hline \multicolumn{7}{c}{ Correlations } \\
\hline & & penanganan & penanganan & penanganan & penanganan & skor \\
& & 1 & 2 & 3 & 4 & total \\
\hline penanganan & Pearson Correlation & 1 & $.276^{* *}$ & $.584^{* *}$ & $.434^{* *}$ & $.768^{* *}$ \\
1 & Sig. (2-tailed) & & .027 &, 000 &, 000 &, 000 \\
& $\mathrm{~N}$ & 64 & 64 & 64 & 64 & 64 \\
penanganan & Pearson Correlation & $.276^{*}$ & 1 & $.494^{* *}$ & $.446^{* *}$ & $.692^{* *}$ \\
2 & Sig. (2-tailed) & .027 & & .000 & .000 & .000 \\
& $\mathrm{~N}$ & 64 & 64 & 64 & 64 & 64 \\
penanganan & Pearson Correlation & $.584^{* *}$ & $.494^{* *}$ & 1 & $.514^{* *}$ & $.839^{* *}$ \\
3 & Sig. (2-tailed) & .000 &, 000 & &, 000 &, 000 \\
& $\mathrm{~N}$ & 64 & 64 & 64 & 64 & 64 \\
penanganan & Pearson Correlation & $.434^{* *}$ & $.446^{* *}$ & $.514^{* *}$ & 1 & $.780^{* *}$ \\
4 & Sig. (2-tailed) & .000 & .000 & .000 & & .000 \\
& N & 64 & 64 & 64 & 64 & 64 \\
skor total & Pearson Correlation & $.768^{* *}$ & $.692^{* *}$ & $.839^{* *}$ & $.780^{* * *}$ & 1 \\
& Sig. (2-tailed) & .000 & .000 & .000 & .000 & \\
& $\mathrm{~N}$ & 64 & 64 & 64 & 64 & 64 \\
\hline
\end{tabular}

*: Correlation is significant at the 0.05 level (2-tailed)

**: Correlation is significant at the 0.01 level (2-tailed)

Tabel 5. Output Validitas Pelaksanaan

\begin{tabular}{|c|c|c|c|c|c|c|}
\hline \multicolumn{7}{|c|}{ Correlations } \\
\hline & & $\begin{array}{c}\text { pelaksanaan } \\
1\end{array}$ & pelaksanaan 2 & $\begin{array}{c}\text { pelaksana } \\
3\end{array}$ & $\begin{array}{c}\text { laksanaan } \\
4\end{array}$ & skor total \\
\hline \multirow{3}{*}{$\begin{array}{c}\text { pelaksanaan } \\
1\end{array}$} & Pearson Correlation & 1 & $.516^{* *}$ & .230 & .101 & $.608^{* *}$ \\
\hline & Sig. (2-tailed) & & ,000 & .068 & .426 & .000 \\
\hline & $\mathrm{N}$ & 64 & 64 & 64 & 64 & 64 \\
\hline \multirow{3}{*}{$\begin{array}{c}\text { pelaksanaan } \\
2\end{array}$} & Pearson Correlation & $.516^{* *}$ & 1 & $.559^{* *}$ & $.399^{* *}$ & $.834^{* *}$ \\
\hline & Sig. (2-tailed) &, 000 & & ,000 & ,001 &, 000 \\
\hline & $\mathrm{N}$ & 64 & 64 & 64 & 64 & 64 \\
\hline \multirow{3}{*}{$\begin{array}{c}\text { pelaksanan } \\
3\end{array}$} & Pearson Correlation & .230 & $.559^{* *}$ & 1 & $.474^{* *}$ & $.768^{* *}$ \\
\hline & Sig. (2-tailed) & .068 & .000 & & .000 & .000 \\
\hline & $\mathrm{N}$ & 64 & 64 & 64 & 64 & 64 \\
\hline \multirow{3}{*}{$\begin{array}{c}\text { pelaksanaan } \\
4\end{array}$} & Pearson Correlation & .101 & $.399^{* * *}$ & $.474^{* *}$ & 1 & $.711^{* *}$ \\
\hline & Sig. (2-tailed) & .426 &, 001 & .000 & & .000 \\
\hline & $\mathrm{N}$ & 64 & 64 & 64 & 64 & 64 \\
\hline \multirow[t]{3}{*}{ skor total } & Pearson Correlation & $.608^{* *}$ & $.834^{* *}$ & $.768^{* *}$ & $.711^{* * *}$ & 1 \\
\hline & Sig. (2-tailed) & .000 & .000 & .000 & .000 & \\
\hline & $\mathrm{N}$ & 64 & 64 & 64 & 64 & 64 \\
\hline
\end{tabular}

**: Correlation is significant at the 0.01 level (2-tailed) 
Tabel 6. Output Validitas Residual dan Lain-Lain

\begin{tabular}{|c|c|c|c|c|}
\hline \multicolumn{5}{|c|}{ Correlations } \\
\hline & & Residual & lain lain & skor total \\
\hline \multirow[t]{3}{*}{ Residual } & Pearson Correlation & 1 & $.495^{* *}$ & $.912^{* *}$ \\
\hline & Sig. (2-tailed) & & .000 & .000 \\
\hline & $\mathrm{N}$ & 64 & 64 & 64 \\
\hline \multirow[t]{3}{*}{ lain lain } & Pearson Correlation & $.495^{* *}$ & 1 & $.808^{* *}$ \\
\hline & Sig. (2-tailed) & .000 & & .000 \\
\hline & $\mathrm{N}$ & 64 & 64 & 64 \\
\hline \multirow[t]{3}{*}{ skor total } & Pearson Correlation & $.912^{* *}$ & $.808^{* *}$ & 1 \\
\hline & Sig. (2-tailed) & .000 & .000 & \\
\hline & $\mathrm{N}$ & 64 & 64 & 64 \\
\hline
\end{tabular}

**: Correlation is significant at the 0.01 level (2-tailed)

Dari hasil uji diatas menunjukkan seluruh faktor yang mempengaruhi sisa material baik dari desain hingga lain lain dapat dipergunakan.

\subsection{Uji Reliabilitas}

Uji ini digunakan untuk mengetahui apakah alat ukur pada kuesioner ini konsistensi atau tidak. Uji ini menggunakan metode Alpha Conbrach's. Apabila nilai Alpha Conbrach's kurang dari 0.6 (Gozali, 2001) maka alat ukur dikatakan tidak reliabel. Sedangkan lebih dari 0.6 maka alat ukur dikatakan reliabel.

Tabel 7. Uji Reliabilitas Seluruh Faktor

\begin{tabular}{cc}
\hline \multicolumn{2}{c}{ Reliability Statistics } \\
\hline Cronbach's Alpha & N of Items \\
\hline .914 & 18 \\
\hline Hasil output menyatakan $0.914>0.6$
\end{tabular}

maka dapat dikatakan reliabel sehingga seluruh faktor dari desain hingga lain lain dapat dipergunakan (Tabel 7).
Selanjutnya adalah uji reliabilitas per masing masing faktor utama dapat dilihat pada Tabel 8 yang menunjukkan $\mathrm{R} \alpha$ lebih besar dari $\mathrm{R}$ tabel yakni 0.6 sehingga seluruh faktor dinyatakan reliabel hingga layak dipergunakan dengan data sebagai berikut:

Tabel 8. Hasil Uji Reliabilitas

\begin{tabular}{clcc}
\hline No & \multicolumn{1}{c}{ Jenis } & $\mathrm{R} \alpha$ & $\mathrm{R}$ tabel \\
\hline 1 & Desain & 0.825 & 0.6 \\
2 & Pengadaan & 0.763 & 0.6 \\
3 & Pelaksanaan & 0.703 & 0.6 \\
4 & Penanganan & 0.770 & 0.6 \\
5 & Residual & 0.634 & 0.6 \\
\hline
\end{tabular}

\subsection{Relative Importance Index (RII) Secara Umum}

Sebelum dilakukan RII, dilakukan pendataan untuk tiap-tiap variabel yang telah memenuhi uji validitas dan uji reliabilitas sehingga di dapat hasilnya sebagai faktor yang dapat digunakan, dan 
dengan dilakukan RII untuk mendapatkan hasil peringkat faktor yang mempengaruhi kerugian beton ready mix dengan nilai RII yang terdapat pada Tabel 9 berdasarkan dari faktor faktor utama yang mempengaruhinya, dimana faktor utama adalah desain, pengadaan, penanganan, pelaksanaan, residual dan lain lain. Berdasarkan Ciccheti ,1994 maka hasil dari RII dikatakan sangat baik bila berkisar diantara 0.75 hingga 1 , dan dibawah ini semua hasil RII menunjukkan hasil survey yang sangat karena berada di atas 0.75 .

Tabel 10 menjelaskan peringkat penyebab kerugian beton ready mix secara keseluruhan berdasarkan peringkat dari tertinggi hingga yang terendah. Tabel 11 menjelaskan nilai perhitungan RII rata rata untuk mengetahui pengaruh kerugian beton ready mix berdasarkan masing masing faktor utama.

\section{Tabel 9. Nilai Perhitungan RII Untuk Setiap Faktor}

Faktor yang mempengaruhi kerugian beton ready Mix

RII

1. Desain

a. Adanya perubahan desain

0.87

b. Informasi gambar kurang/tidak jelas

0.86

c. Pendetailan gambar yang rumit

0.87

d. Kurang berkoordinasi terhadap dimensi produk yang digunakan adanya perubahan desain

2. Pengadaan Material
a. Pesanan material tidak sesuai spesifikasi
0.86
b. Pemesanan melebihi kebutuhan
0.85
c. Pesanan tidak dapat dilakukan dalam jumlah kecil
0.85
d. Supplier kirim material tidak sesuai spesifikasi
0.85

3. Penanganan Material
a. Penanganan yang tidak hati-hati/kecelakaan pada saat menuangkan beton
b. Volume beton dari levaransir kurang
0.84
c. Beton mengeras karena penanganan lambat
d. Tercecer pada saat diangkut/dipindahkan

4. Pelaksanaan Material
a. Cuaca yang buruk/hujan
0.86
b. Pengukuran dimensi tidak akurat
0.86
c. Terjadi deviasi dimensi struktur pada saat pengecoran
0.85
d. Letak tiang pancang bergeser menyebabkan volume poer/sloof bertambah
0.83

5. Residual
a. Sisa material pada akhir pekerjaan
0.86

6. Lain Lain

a. Hilang karena dicuri

0.88 
Tabel 10. Peringkat Penyebab Kerugian Beton Ready Mix

\begin{tabular}{|c|c|c|c|}
\hline Peringkat & $\begin{array}{c}\text { Indikator yang mempengaruhi Kerugian Beton } \\
\text { Ready Mix }\end{array}$ & Variabel Faktor & RII \\
\hline 1 & Hilang karena dicuri & Lain lain & 0.88 \\
\hline 2 & Adanya perubahan desain & Desain & 0.87 \\
\hline 3 & Pendetailan gambar yang rumit & Desain & 0.87 \\
\hline 4 & Pesanan material tidak sesuai spesifikasi & $\begin{array}{l}\text { Pengadaan } \\
\text { Material }\end{array}$ & 0.87 \\
\hline 5 & Tercecer pada saat diangkut/dipindahkan & $\begin{array}{l}\text { Penanganan } \\
\text { Material }\end{array}$ & 0.87 \\
\hline 6 & Informasi gambar kurang/tidak jelas & Desain & 0.86 \\
\hline 7 & Sisa material pada akhir pekerjaan & Residual & 0.86 \\
\hline 8 & Cuaca yang buruk/hujan & $\begin{array}{l}\text { Pelaksanaan } \\
\text { Material }\end{array}$ & 0.86 \\
\hline 9 & Pengukuran dimensi tidak akurat & $\begin{array}{l}\text { Pelaksanaan } \\
\text { Material }\end{array}$ & 0.86 \\
\hline 10 & Pemesanan melebihi kebutuhan & $\begin{array}{l}\text { Pengadaan } \\
\text { Material }\end{array}$ & 0.86 \\
\hline 11 & Supplier kirim material tidak sesuai spesifikasi & $\begin{array}{l}\text { Pengadaan } \\
\text { Material }\end{array}$ & 0.86 \\
\hline 12 & Pesanan tidak dapat dilakukan dalam jumlah kecil & $\begin{array}{l}\text { Pengadaan } \\
\text { Material }\end{array}$ & 0.85 \\
\hline 13 & $\begin{array}{l}\text { Penanganan yang tidak hati-hati/kecelakaan pada } \\
\text { saat menuangkan beton }\end{array}$ & $\begin{array}{l}\text { Penanganan } \\
\text { Material }\end{array}$ & 0.85 \\
\hline 14 & $\begin{array}{l}\text { Terjadi deviasi dimensi struktur pada saat } \\
\text { pengecoran }\end{array}$ & $\begin{array}{l}\text { Pelaksanaan } \\
\text { Material }\end{array}$ & 0.85 \\
\hline 15 & Beton mengeras karena penanganan lambat & $\begin{array}{l}\text { Penanganan } \\
\text { Material }\end{array}$ & 0.85 \\
\hline 16 & Volume beton dari levaransir kurang & $\begin{array}{l}\text { Penanganan } \\
\text { Material }\end{array}$ & 0.84 \\
\hline 17 & $\begin{array}{l}\text { Letak tiang pancang bergeser menyebabkan } \\
\text { volume poer/sloof bertambah }\end{array}$ & $\begin{array}{l}\text { Pelaksanaan } \\
\text { Material }\end{array}$ & 0.83 \\
\hline 18 & $\begin{array}{l}\text { Kurang berkoordinasi terhadap dimensi produk } \\
\text { yang digunakan Adanya perubahan desain }\end{array}$ & Desain & 0.83 \\
\hline
\end{tabular}

Tabel 11. Nilai Perhitungan RII Rerata untuk Penyebab Kerugian Beton Ready Mix

\begin{tabular}{cc}
\hline Faktor yang mempengaruhi Kerugian Beton & Nilai rata-rata RII \\
Ready Mix & 0.85 \\
\hline Desain & 0.86 \\
Pengadaan Material & 0.85 \\
Penanganan Material & 0.85 \\
Pelaksanaan & 0.86 \\
Residual & 0.88 \\
Lain lain &
\end{tabular}




\section{SIMPULAN}

Menyajikan kesimpulan penelitian dan saran-saran yang mengacu pada hasilhasil penelitian. Setelah dilakukan pengolahan data hasil penelitian, dapat ditarik kesimpulan beberapa hal yaitu kerugian beton ready mix sebesar $9.06 \%$.

Yang mempengaruhi kerugian beton ready mix adalah:

1. Hilang karena dicuri

2. Adanya perubahan desain

3. Pendetailan gambar yang rumit

4. Pesanan material yang tidak sesuai dengan spesifikasi

\section{DAFTAR PUSTAKA}

Bossink, B. A. G., \& Brouwers, H. J. H. (1996). Construction Waste: Quantification and Source Evaluation. Journal of Construction Engineering and Management, 122(1), 55-60. https://doi.org/10.1061/(ASCE)07339364(1996)122:1(55)

Cicchetti, D. V. (1994). Guidelines, criteria, and rules of thumb for evaluating normed and standardized assessment instruments in psychology. Psychological Assessment, 6(4), 284290. https://doi.org/10.1037/10403590.6.4.284

Cronbach, L. J. (1951). Coefficient alpha and the internal structure of tests. Psychometrika, 16(3), 297-334. https://doi.org/10.1007/BF02310555

Formoso, C. T., Soibelman, L., De Cesare, C., \& Isatto, E. L. (2002). Material Waste in Building Industry: Main
Causes and Prevention. Journal of Construction Engineering and Management, 128(4), 316-325. https://doi.org/10.1061/(ASCE)07339364(2002)128:4(316)

Garson, G. D. (2009). Structural equation modeling, from statnotes.

Gavilan, R. M., \& Bernold, L. E. (1994). Source Evaluation of Solid Waste in Building Construction. Journal of Construction Engineering and Management, 120(3), 536-552. https://doi.org/10.1061/(ASCE)07339364(1994)120:3(536)

Gozali, I. (2001). Aplikasi Analisis Multivariate Dengan Program SPSS Edisi Pertama. Semarang: Badan Penerbit Universitas Diponegoro.

Hair, J. F., Black, W. C., Babin, B. J., Anderson, R. E., \& Tatham, R. L. (1998). Multivariate data analysis. Upper Saddle River, NJ: Pearson University Press.

Intan, S., Alifen, R. S., \& Arijanto, L. S. (2005). Analisa dan Evaluasi Sisa Material Konstruksi Sumber Penyebab Kuantitas dan Biaya. Civil Engineering Dimension, 7(1), 36-45. https://doi.org/https://doi.org/10.974 4/ced.7.1.pp. 36-45

Kometa, S. T., Olomolaiye, P. O., \& Harris, F. C. (1994). Attributes of UK construction clients influencing project consultants' performance. Construction Management and Economics, 12(5), 433-443. https://doi.org/10.1080/01446199400 000053

Linkert, R. (1932). A Technique for the Measurement of Attitudes. New York: Archives of Psychology.

Nugraha, P. (1985). Manajemen Proyek Konstruksi 1. Surabaya: Kartika Yudha. 
Nunnally, J. C. (1994). Psychometric Theory 3E. Tata McGraw-Hill Education.

Pearson, K. (1896). Mathematical contributions to the theory of evolution.--III. Regression, heredity, and panmixia. Philosophical Transactions of the Royal Society of London. Series A, Containing Papers of a Mathematical or Physical Character, 187, 253-318. https://doi.org/10.1098/rsta.1896.000 7

Ritz, G. J. (1994). Total Construction Project Management. New York: McGraw-Hill Book Company.

Sambasivan, M., \& Soon, Y. W. (2007). Causes and effects of delays in Malaysian construction industry. International Journal of Project Management, 25(5), 517-526. https://doi.org/10.1016/j.ijproman.20 06.11 .007

Skoyles, E. R. (1976). Materials wastage a misuse of resources. Batiment International, Building Research and Practice, 4(4), 232-232. https://doi.org/10.1080/09613217608 550498

Sugiyono. (2010). Metode Penelitian Pendidikan Pendekatan Kuantitatif,Kualitatif, dan $R \& D$. Badung: Alfabeta.

Waty, M., \& Sulistio, H. (2020). Identification of Advance Risks to Sources and Causes of Material Waste in Road Construction Projects. MEDIA KOMUNIKASI TEKNIK SIPIL, 26(1), 104-117. https://doi.org/10.14710/mkts.v26i1. 21817 